WSRC-STI-2007-00262

Revision 0

\title{
CHARACTERIZATION OF DWPF MELTER OFF-GAS QUENCHER AND STEAM ATOMIZED SCRUBBER DEPOSIT SAMPLES
}

Kristine E. Zeigler

Ned E. Bibler

May 2007 


\section{DISCLAIMER}

This report was prepared by Westinghouse Savannah River Company (WSRC) for the United States Department of Energy under Contract No. DE-AC09-96SR18500 and is an account of work performed under that contract. Neither the United States Department of Energy, nor WSRC, nor any of their employees makes any warranty, expressed or implied, or assumes any legal liability or responsibility for the accuracy, completeness, or usefulness, of any information, apparatus, or product or process disclosed herein or represents that its use will not infringe privately owned rights. Reference herein to any specific commercial product, process, or service by trademark, name, manufacturer or otherwise does not necessarily constitute or imply endorsement, recommendation, or favoring of same by WSRC or by the United States Government or any agency thereof. The views and opinions of the authors expressed herein do not necessarily state or reflect those of the United States Government or any agency thereof.

\section{Printed in the United States of America}

Prepared For

U.S. Department of Energy 
WSRC-STI-2007-00262

Revision 0

Key Words:

Primary off-gas deposits

Steam Atomized Scrubber (SAS)

Quencher

DWPF Melter

Retention: Permanent

\section{CHARACTERIZATION OF DWPF MELTER OFF-GAS QUENCHER AND STEAM ATOMIZED SCRUBBER DEPOSIT SAMPLES}

Kristine E. Zeigler

Ned E. Bibler

May 2007

Savannah River National Laboratory

Aiken, SC 29808

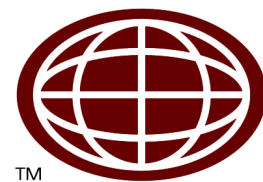




\section{REVIEWS AND APPROVALS}

\section{AUTHORS:}

Kristine E. Zeigler, Analytical Development

Date

Ned E. Bibler, Process Science \& Engineering

Date

\section{TECHNICAL REVIEWER:}

Alex S. Choi, Process Science \& Engineering

Date

\section{APPROVERS:}

Connie C. Herman, Manager, Process Engineering Technology

Date

Richard E. Edwards, Manager, Process Science \& Engineering Section

Date

John E. Occhipinti, Manager, Process Cognizant Engineering

Date

Waste Solidification Engineering 


\section{EXECUTIVE SUMMARY}

This report summarizes the results from the characterization of deposits from the inlets of the primary off-gas Quencher and Steam Atomized Scrubber (SAS) in the Defense Waste Processing Facility (DWPF), as requested by a technical assistance request. ${ }^{*}$ DWPF requested elemental analysis and compound identification to help determine the potential causes for the substance formation. This information will be fed into Savannah River National Laboratory modeling programs to determine if there is a way to decrease the formation of the deposits. The general approach to the characterization of these samples included x-ray diffraction (XRD), scanning electron microscopy (SEM), and chemical analysis.

The following conclusions are drawn from the analytical results found in this report:

- The deposits are not high level waste glass from the DWPF melt pool based on comparison of the compositions of deposits to the composition of a sample of glass taken from the pour stream of the melter during processing of Sludge Batch 3.

- Chemical composition results suggest that the deposits are probably a combination of sludge and frit particles entrained in the off-gas.

- Gamma emitters, such as Co-60, Cs-137, Eu-154, Am-241, and Am-243 were detected in both the Quencher and SAS samples with Cs-137 having the highest concentration of the gamma emitters.

- No evidence existed for accumulation of fissile material (U-233, U-235, and Pu-239) relative to $\mathrm{Fe}$ in either deposit.

- XRD results indicated both samples were primarily amorphorous and contained some crystals of the iron oxides, hematite and magnetite $\left(\mathrm{Fe}_{2} \mathrm{O}_{3}\right.$ and $\left.\mathrm{Fe}\left(\mathrm{Fe}_{2} \mathrm{O}_{4}\right)\right)$, along with sodium nitrate $\left(\mathrm{NaNO}_{3}\right)$. The other main crystalline compound in the SAS deposit was mercurous chloride. The main crystalline compound in the Quencher deposit was a uranium oxide compound. These are all sludge components.

- SEM analysis of the Quencher deposit revealed crystalline uranium compounds within the sample. SEM analysis of the SAS sample could not be performed due to the presence of a significant concentration of $\mathrm{Hg}$ in the sample.

- Essentially all the $\mathrm{Na}$ and the $\mathrm{S}$ in the off-gas samples were soluble in water.

- The main soluble anion was $\mathrm{NO}_{3}{ }^{-}$with $\mathrm{SO}_{4}{ }^{2-}$ being second.

- In contrast to the results for the off-gas deposits analyzed in $2003,{ }^{3}$ soluble compounds of fluoride and chloride were detected; however, their concentrations in the Quencher and SAS deposits were less than one weight percent.

- The results suggest that the $\mathrm{S}$ is primarily in the deposits as the sulfate anion.

* Barnes, Allan, Characterize Melter Off-Gas Deposits, HLW-DWPF-TAR-2007-0005, January 30, 2007. 
TABLE OF CONTENTS

EXECUTIVE SUMMARY iv

LIST OF FIGURES vi

LIST OF TABLES vi

LIST OF ACRONYMS vii

1.0 INTRODUCTION AND BACKGROUND 1

2.0 EXPERIMENTAL 2

2.1 Visual Observations and Weights 2

2.2 Physical Characterization of the Off-gas Samples 2

2.3 Chemical Composition of the Off-gas Samples 3

3.0 RESULTS 4

3.1 X-Ray Diffraction Results 4

3.2 Scanning Electron Microscopy Analysis 5

3.3 Elemental Analysis $\quad 8$

3.4 Water Leach of Samples $\quad 13$

4.0 CONCLUSIONS 17

5.0 REFERENCES 19

6.0 ACKNOWLEDGEMENTS 21 


\section{LIST OF FIGURES}

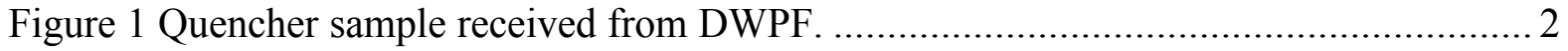

Figure 2 Steam Atomized Scrubber (SAS) sample. ........................................... 2

Figure 3 XRD diffraction pattern for a sample of the Quencher material.......................... 4

Figure 4 XRD diffraction pattern for a sample of the SAS material................................... 5

Figure 5 SEM full image EDX scan of a portion of Quencher sample \#1, showing

a typical representation of the contents of the sample. ....................................... 6

Figure 6 SEM image of Quencher sample \#1 ....................................................... 6

Figure 7 SEM image of crystalline features in the Quencher sample \#2 ............................ 7

Figure 8 SEM image of Quencher sample \#2 ................................................... 8

\section{LIST OF TABLES}

Table 1 Results from ICP-ES of the digestions for the Quencher samples. ...................... 9

Table 2 Radionuclide results, measured by gamma counting, of the Quencher samples..... 10

Table 3 Results from ICP-MS of the aqua regia digestion of the Quencher samples.......... 10

Table 4 Results from ICP-ES of the digestions for the SAS samples. ........................... 11

Table 5 Radionuclide results, measured by gamma counting, of the SAS samples............. 11

Table 6 Results from ICP-MS of the aqua regia digestion of the SAS samples................. 12

Table 7 Ratio values of elements found in the Quencher and SAS compared to the same ratios from Sludge Batch 3 and Frit 418......................................... 13

Table 8 Ratio values of Fe compared to the sum of U-233, Pu-239 and U-235 for the Quencher and SAS samples and SB-3.

Table 9 Weight percent of elements and anions from the off-gas samples dissolved in water.

Table 10 Fraction of elements or anions leached in the Quencher and SAS samples based on the $\mathrm{wt} \%$ of the sample from the digestions and the weight percent of the soluble elements from the water leach. 


\section{LIST OF ACRONYMS}

$\begin{array}{ll}\text { AD } & \text { Analytical Development } \\ \text { CV AA } & \text { Cold vapor Atomic absorption (spectroscopy) } \\ \text { DWPF } & \text { Defense Waste Processing Facility } \\ \text { EDX } & \text { Energy dispersive x-ray } \\ \text { IC } & \text { Ion chromatography } \\ \text { ICP } & \text { Inductively coupled plasma (spectroscopy) } \\ \text { ICP-ES } & \text { Inductively coupled plasma - (atomic) emission spectroscopy } \\ \text { ICP-MS } & \text { Inductively coupled plasma - mass spectroscopy } \\ \text { NA } & \text { Non-applicable } \\ \text { ND } & \text { Not determined } \\ \text { OGCT } & \text { Off-gas condensate tank } \\ \text { POG } & \text { Primary off-gas } \\ \text { PS\&E } & \text { Process Science \& Engineering } \\ \text { RSD } & \text { Relative Standard Deviation } \\ \text { SAS } & \text { Steam atomized scrubber } \\ \text { SB3 } & \text { Sludge Batch 3 } \\ \text { SEM } & \text { Scanning electron microscopy } \\ \text { SRNL } & \text { Savannah River National Laboratory } \\ \text { TAR } & \text { Technical assistance request } \\ \text { XRD } & \text { X-ray diffraction }\end{array}$




\subsection{INTRODUCTION AND BACKGROUND}

In April 2007, Savannah River National Laboratory (SRNL) received two deposit samples from the Defense Waste Processing Facility's (DWPF) Melter Primary Off-Gas System (POG). These samples were material that had collected from the inlets of both the Quencher and the Steam Atomized Scrubber (SAS). Through a technical assistance request, ${ }^{1}$ DWPF requested characterization of the melter off-gas deposits by x-ray diffraction (XRD), scanning electron microscopy (SEM), and chemical analysis. After the characterization, results will be fed to the Process Science \& Engineering (PS\&E) melter and off-gas modeling program in an attempt to improve understanding of the off-gas system performance.

The purpose of the Melter Off-Gas System is to reduce the amount of radioactive particles and mercury in the gases vented to the atmosphere. ${ }^{2}$ Gases emitted from the melter pass through the primary film cooler, Quencher, Off-Gas Condensate Tank (OGCT), Steam Atomized Scrubbers, a condenser, a high efficiency mist eliminator, and a high efficiency particulate air filter, before being vented to the Process Vessel Vent System. $^{2}$

The film coolers cool the gases leaving the melter vapor space from $\sim 750^{\circ} \mathrm{C}$ to $\sim 375^{\circ} \mathrm{C}$, by introducing air and steam to the flow. ${ }^{2}$ In the next step, the Quencher cools the gas to about $60^{\circ} \mathrm{C}$ by bringing the condensate from the OGCT in contact with the effluent. Most of the steam in the effluent is then condensed and the melter vapor space pressure is reduced. The purpose of the OGCT is to collect and store the condensate formed during the melter operation. Condensate from the OGCT is circulated to the SAS and atomized with steam and then this atomized condensate is mixed with the off-gas to wet and join the particulate which is then removed in the cyclone. The next stage incorporates a chilled water condenser which separate the vapors and elemental mercury from the off-gas steam. ${ }^{2}$

Primary off-gas deposit samples from the DWPF Melter have previously been analyzed. In 2003, samples from just past the film cooler, from the inlet of the Quencher and inside the Quencher were analyzed at SRNL. ${ }^{3}$ It was determined that the samples were a mixture of sludge and glass frit. The major component was $\mathrm{Si}$ along with $\mathrm{Fe}, \mathrm{Al}$, and other elements in the radioactive waste being processed. The deposits analyzed also contained U-235 fission products and actinide elements. Prior to that, pluggages to the off-gas system in the DWPF nonradioactive half scale melter and the one-tenth scale integrated DWPF melter system were analyzed and determined to be mixtures of alkali rich chlorides, sulfates, borates, and fluorides entrained with iron oxides, spinels and frit particles formed by vapor-phase transport and condensation. ${ }^{4}$

According to DWPF Engineering, the Quencher is changed out every 3.5 to 4 months due to the accumulation of the deposits. The last time the SAS was cleaned out was in 2003-2004. Therefore, the material collected should contain constituents of what has been processed within the past 3-4 years for the SAS and the last few months for the Quencher. Results from the analyses will hopefully aid in determining how to decrease the accumulation of these deposits in the future. 


\subsection{EXPERIMENTAL}

\subsection{Visual Observations and Weights}

The samples received by SRNL had been taken from DWPF in two places: the inlet of the Quencher and the inlet of the SAS. The Quencher sample was a dark black color and appeared somewhat damp. The sample had the appearance of crushed chocolate cookies, as seen on the right side of Figure 1. The left side of Figure 1 shows a close-up picture of the sample. (Colors and contrast have been adjusted to better view the picture.) The total amount of material received was $\sim 48$ grams.

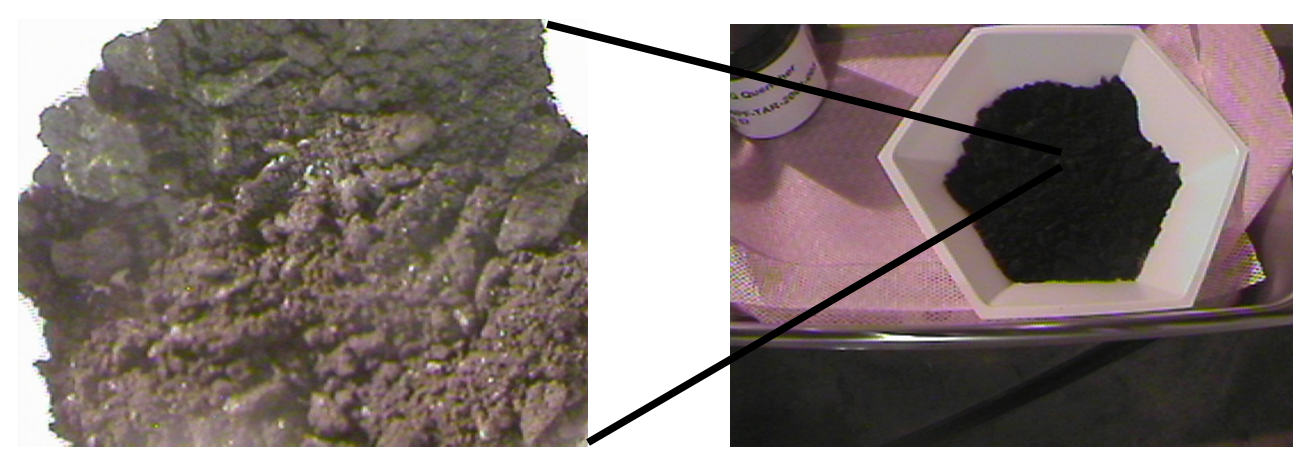

Figure 1 Quencher sample received from DWPF.

The sample from the SAS appeared as light gray dust with a few clumps in it, as seen in Figure 2. It was very dry looking and appeared to be homogenous, just as the Quencher sample did. (The SAS sample had been taken about 5 months prior to receiving it and had sat in a storage area for that time.) The amount of SAS material received was $\sim 31$ grams.

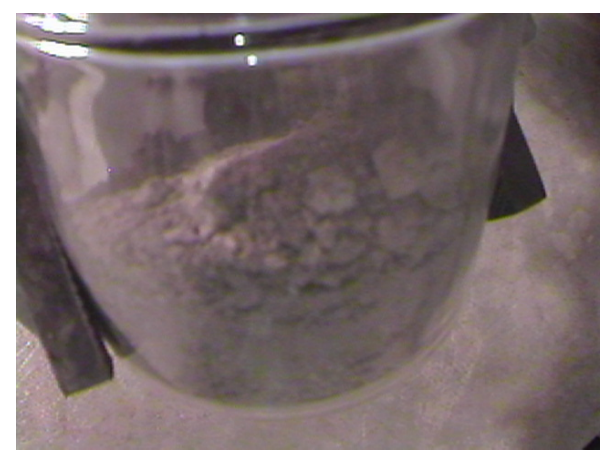

Figure 2 Steam Atomized Scrubber (SAS) sample.

\subsection{Physical Characterization of the Off-gas Samples}

Small quantities of both the SAS and Quencher deposits were submitted for characterization by XRD and SEM. XRD analysis provides information about the crystalline form(s) in the sample, while SEM provides qualitative elemental analysis for specific areas on the sample using energy dispersive X-ray 
analysis (EDX). Minimal sample preparation is needed for these types of characterizations.

\subsection{Chemical Composition of the Off-gas Samples}

Small amounts of each sample were dissolved using the aqua regia digestion technique and the peroxide fusion technique. Both of these methods are routine analytical methods used by Analytical Development (AD) for dissolving radioactive samples.

For the aqua regia digestions, a known amount of sample $(\sim 0.25$ grams $)$ was dissolved in $3 \mathrm{~mL}$ of concentrated nitric acid and $9 \mathrm{~mL}$ of concentrated hydrochloric acid in a sealed vessel for 2 hours in a $95^{\circ} \mathrm{C}$ oven. After the sample was cooled, it was diluted to a known volume $(100 \mathrm{~mL})$. A sealed vessel is used to ensure that any elements volatized during the process, such as mercury, are retained in the solution during the dissolution. A standard glass is also dissolved and analyzed with the samples to ensure the dissolutions were performed correctly and the analyses were accurate. With all dissolutions, a blank is also included with all of the steps followed in the procedure except for the addition of a sample. This helps check for impurities in the reagents or contamination that may have occurred during work in the Shielded Cells. For the aqua regia digestions, triplicate analyses were performed. It was noted that a small amount of the solids in both the SAS and the Quencher samples had not dissolved using the aqua regia method.

The peroxide fusion digestion provides a check for the results from the aqua regia analysis as well as allows for the elements that the aqua regia analysis does not digest well, such as aluminum and silicon, to be obtained. For the peroxide fusion method, the sample is fused in a zirconium crucible with a mixture of sodium peroxide and sodium hydroxide for 10 minutes in a $675^{\circ} \mathrm{C}$ oven. The sample is briefly cooled and then water is added until the melt at the bottom of the crucible dissolves. A small amount of nitric acid is added to help dissolution and the complete solution is diluted with water to exactly $250 \mathrm{~mL}$. A standard glass and blank were also performed using the peroxide fusion method. Duplicate samples of each off-gas sample were dissolved by this method.

About 10-15 mL of the prepared solutions were removed from the Shielded Cells and submitted to AD for analysis. Aqua regia samples were analyzed using inductively coupled plasma- (atomic) emission spectroscopy (ICP-ES), inductively coupled plasma- mass spectroscopy (ICP-MS), and cold vapor atomic absorption spectroscopy (CV AA) for mercury. Peroxide fusion samples were submitted for ICP-ES and also for a gamma scan analysis to measure the major gamma emitters.

A water leach of both the SAS and the Quencher samples was also performed. The purpose of the water leach was to determine the water soluble compounds in the samples. A known amount of sample $(\sim 1$ gram) was added to a known amount of water $(\sim 100 \mathrm{~mL})$ and allowed to sit, with intermittent shaking for approximately 3.5 days. The resulting solution was filtered through a 0.45 micron filter attached to a syringe. Samples were then submitted for ICP-ES, Hg analysis, and anion analysis by ion chromatography (IC). 


\subsection{RESULTS}

\subsection{X-Ray Diffraction Results}

Two samples of microgram quantities of the POG Quencher and SAS deposits were submitted for XRD analysis. Personnel dose rate readings for these four samples exiting the cells were 1 mrem whole body and 280 mrem extremity.

Results of XRD analysis of the Quencher and SAS deposits are shown in Figures 3 and 4. Results for both indicated that the deposits were amorphous but did contain some crystalline compounds. The diffraction patterns shown in Figures 3 and 4 have been corrected by removal of the broad peak indicating that the deposits contained amorphous compounds. As a result, the two theta peaks can be assigned more easily to crystalline compounds. Both deposits contained hematite $\left[\mathrm{Fe}_{2} \mathrm{O}_{3}\right]$, nitratine $\left[\mathrm{NaNO}_{3}\right]$, and magnetite $\left[\mathrm{Fe}\left(\mathrm{Fe}_{2} \mathrm{O}_{4}\right)\right]$. Other specific compounds which matched the diffraction pattern, shown in Figure 3 , for the Quencher material included, clarkeite $\left[\left(\mathrm{Na}\left(\left(\mathrm{UO}_{2}\right) \mathrm{O}\right)(\mathrm{OH}) \cdot\left(\mathrm{H}_{2} \mathrm{O}\right)\right]\right.$, schoepite $\left[\mathrm{UO}_{3} \cdot 2 \mathrm{H}_{2} \mathrm{O}\right]$, and anhydrite $\left[\mathrm{CaSO}_{4}\right]$. However, hematite was the main crystalline compound present. XRD analysis of the second sample of the Quencher deposits indicated the presence of the compound Soddyite $\left[\left(\mathrm{UO}_{2}\right)_{2}\left(\mathrm{SiO}_{4}\right) \cdot 2 \mathrm{H}_{2} \mathrm{O}\right]$ in small quantities (along with the other compounds shown in Figure 3), confirming that on a micro scale the Quencher sample was not homogenous.

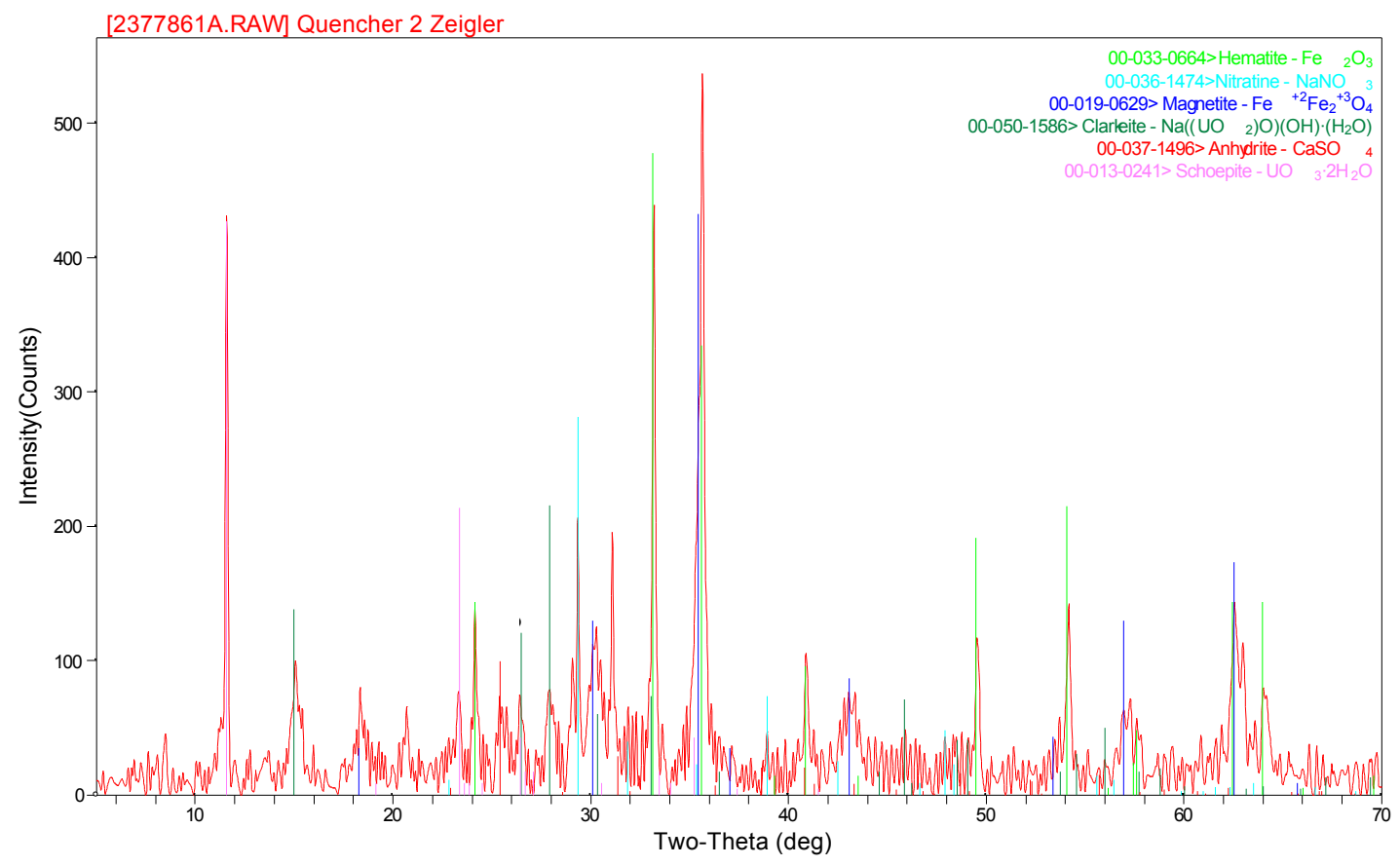

Figure 3 XRD diffraction pattern for a sample of the Quencher material.

XRD analysis of two samples from the SAS sample indicated that it contained the same iron and sodium compounds as in the Quencher sample, however its main crystalline constituent was mercurous chloride (calomel). The presence of calomel is clearly shown in Figure 4. The diffraction pattern for the other 
SAS sample identified a possible match of cesium sodium aluminum silicate hydrate [ $\mathrm{NaCsAlSiO} \cdot \mathrm{xH}_{2} \mathrm{O}$ ], which is not shown in Figure 4. This was a fair match however, and again the data showed the inhomogeneity of the sample.

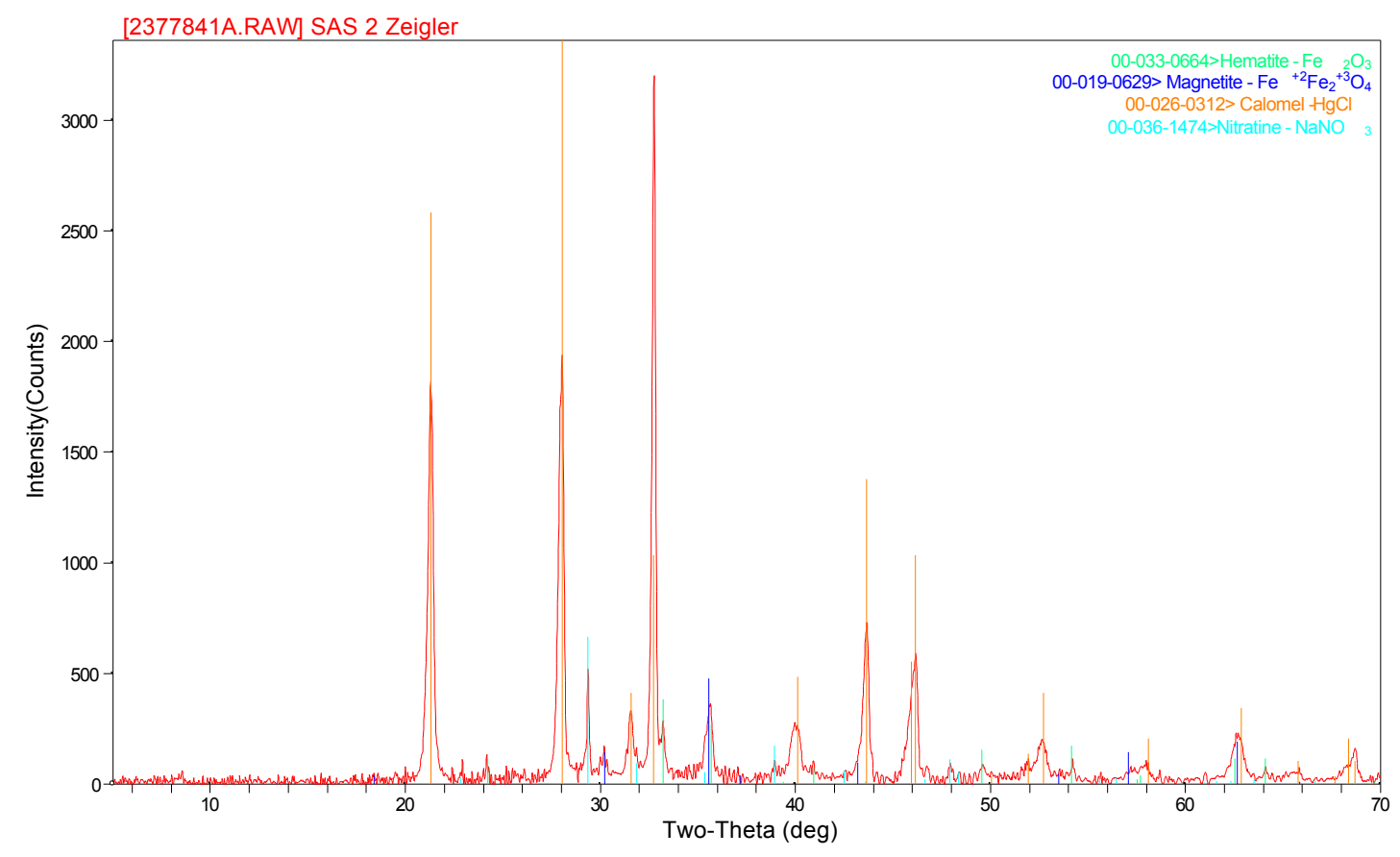

Figure 4 XRD diffraction pattern for a sample of the SAS material.

\subsection{Scanning Electron Microscopy Analysis}

Small amounts of the Quencher and SAS samples $(\sim 1 \mathrm{mg})$ were submitted for SEM. These samples were placed on two separate SEM stubs in the Shielded Cells. Upon removal, personnel dose rate readings were 1 mrem whole body and only 52 mrem extremity, because of the smaller amount of sample used for SEM analysis. Due to the fact that the XRD revealed the SAS sample contained mercury, SEM on those samples was not performed. When the electron beam is focused on a sample which contains mercury, the mercury vaporizes and coats on the detector. This causes problems for the detector, as the mercury cannot be removed and will report false readings of mercury on subsequent samples. Therefore, AD requested that SEM analysis not be performed on the SAS samples.

A full image EDX scan, which is taken when the electron beam is rastered over large areas of several particles, revealed the first Quencher sample (\#1) to contain iron, sodium, aluminum, silicon, phosphorous, sulfur, uranium, calcium, manganese, nickel and traces of copper. It is believed that the Quencher material is uranium entrained with sludge and frit. Figure 5 shows the full image EDX scan of Quencher sample \#1. 


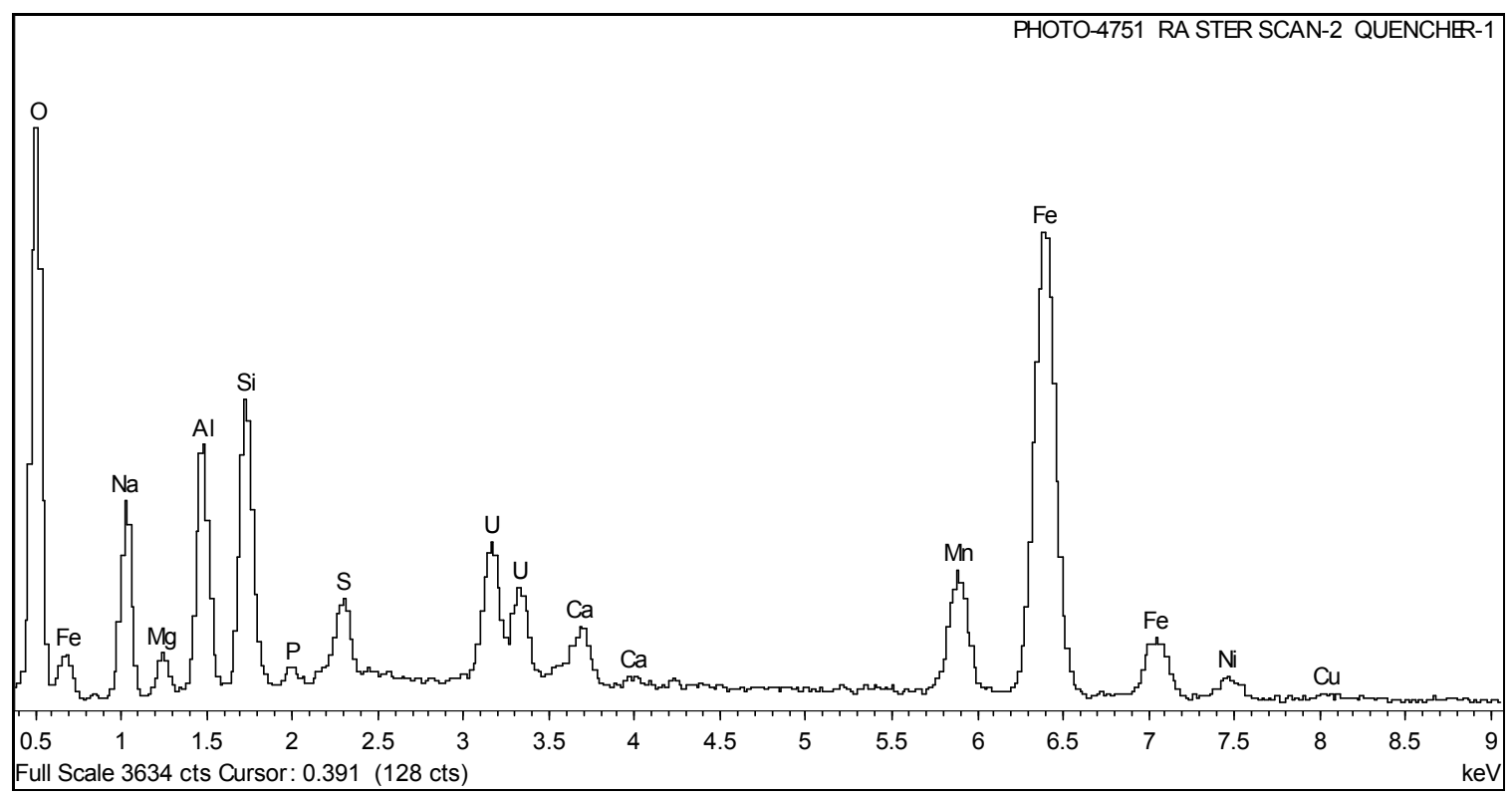

Figure 5 SEM full image EDX scan of a portion of Quencher sample \#1, showing a typical representation of the contents of the sample.

Figure 6 shows a typical image of Quencher sample \#1. In this particular picture, spot 1 had large peaks of iron and uranium and the elements found in the previous EDX scan (Figure 5). Spot 2 contained large peaks of sodium and sulfur, along with aluminum, magnesium, silicon, uranium, calcium and iron. The lighter areas on this picture indicate heavier elements, which included uranium in this case. Other elements, such as silver, chlorine and thorium, were found in other areas on the sample. These were in isolated areas on the sample.

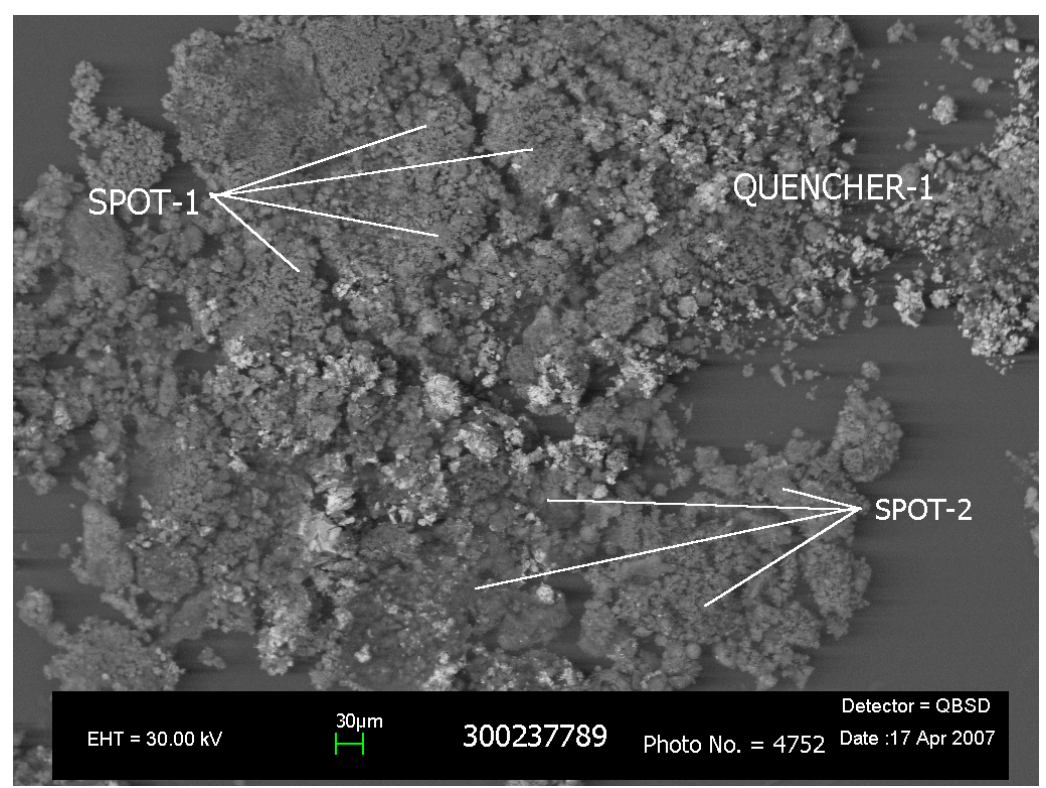

Figure 6 SEM image of Quencher sample \#1. 
The second Quencher sample (\#2) examined by SEM revealed an interesting crystalline structure. Figure 7 shows crystals of uranium contained within the sample (spot 7). These crystalline features were not seen in the previous Quencher sample, indicating again that the sample was not homogenous. Spot 6 on this image contains aluminum and a small amount of copper.

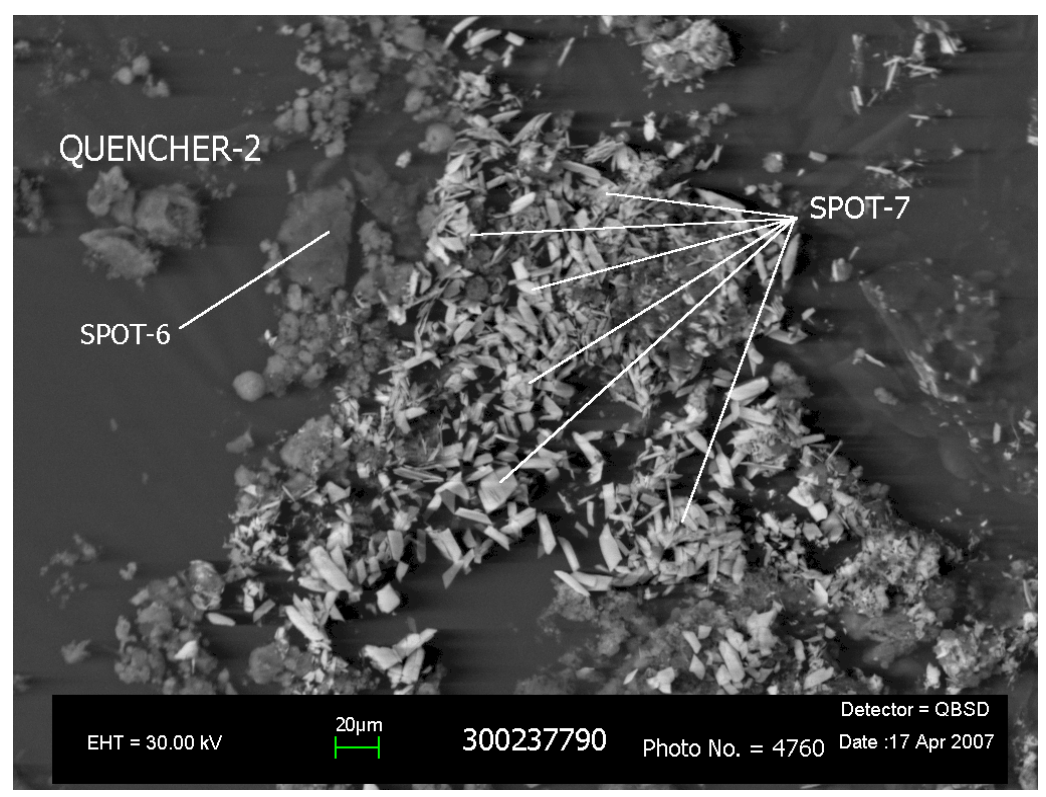

Figure 7 SEM image of crystalline features in the Quencher sample \#2.

The full image EDX scan of this sample was the same spectra as Quencher sample \#1 (Figure 5). Other images, such as Figure 8, showed sulfur and calcium to be the major components (spot 4) as well as sodium, the major peak in the spectra (spot 5). 


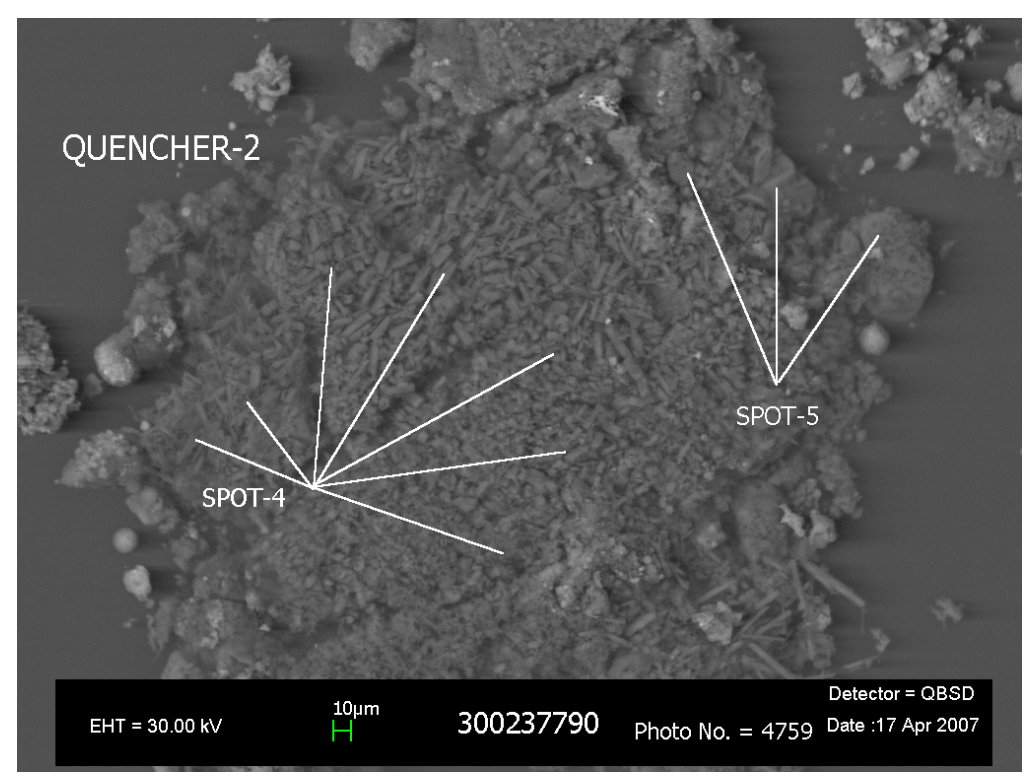

Figure 8 SEM image of Quencher sample \#2.

\subsection{Elemental Analysis}

Compositional results from the Quencher and SAS samples are presented in the following six tables. Tables 1 through 3 contain information on the Quencher sample, while Tables 4 through 6 contain information about the SAS sample. Tables 1 and 4 give the ICP-ES results for the samples. The elemental concentration (in weight percent), the average of the three replicates, and the percent relative standard deviation (\%RSD) are given. Also in Table 1, the elemental concentration of Sludge Batch $3^{5}$ (SB3) can be found. SB3 is used as a comparison because this is the last sludge that was processed before these deposits were removed. This concentration is given in weight percent also. In the case of the peroxide fusion analysis, only duplicate analysis was performed and, therefore, the average is of the two samples. Tables 2 and 5 show the radionuclides measured by gamma counting. The concentration of radionuclides, in microcuries per gram, along with the average and \%RSD, are provided. ND indicates the concentration was below the limits of detection for that method. Tables 3 and 6 give the ICP-MS results for selected isotopes from the aqua regia digestion. Again, the isotope is listed along with its concentration (in weight percent), the average of the three replicates and the percent relative standard deviation (\%RSD). It was noted that all of the solids in both the SAS and the Quencher samples had not dissolved using the aqua regia method.

Based on the data in Table 1, the sample taken from the off-gas deposits from the quencher do not contain a significant amount of SB3 high level waste glass from the melt pool in the DWPF melter. Analysis of a sample of glass taken from the pour stream of the melter during SB3 processing showed that the glass contained $1.38 \% \mathrm{Li}, 2.30 \% \mathrm{~B}$, and $23.8 \% \mathrm{Si}^{6}$. As seen in Table 1, all of these concentrations are significantly higher (especially $\mathrm{Si}$ ) than their respective concentrations in the off-gas deposits. The off-gas deposits are probably agglomerates of compounds rather than a homogenous mixture. ${ }^{4}$ Comparing the Quencher data to the SB3 data, the last sludge that was run before these samples were taken, the five elements that are higher in concentration than SB3 are B, Cd, Li, S and Si. The elements which are about the same in concentration with the $\mathrm{SB} 3$ are $\mathrm{Ag}, \mathrm{Ba}, \mathrm{Hg}$, and $\mathrm{Ti}$. In contrast, comparing the components 
found in the earlier off-gas data ${ }^{3}$ where the sample was taken $\sim 4.5$ years ago, most of the elements from this 2007 sample are found to be in slightly higher concentrations in the particles. The elements present at higher concentrations are $\mathrm{Ca}, \mathrm{Cd}, \mathrm{Mg}, \mathrm{Na}, \mathrm{Ni}, \mathrm{S}, \mathrm{Sr}$, and $\mathrm{U}$. Both $\mathrm{U}-235$ and $\mathrm{Pu}-239$, seen in Table 3, were also higher. The elements of lower concentrations than that reported in the earlier samples ${ }^{3}$ include $\mathrm{Cr}, \mathrm{Fe}, \mathrm{Hg}$ and $\mathrm{Si}$. The $\mathrm{Si}$ is lower by almost 4 times. The elements that did not significantly change in concentration include $\mathrm{Ag}, \mathrm{Al}, \mathrm{Cu}$, and $\mathrm{Li}$.

The Quencher deposit sample was taken at the inlet to the Quencher, where the off-gas temperature is $\sim 330^{\circ} \mathrm{C}$ as it comes from the film coolers (before being mixed with the pressure control air). At this high temperature the vapor pressure of $\mathrm{Hg}$ is $\sim 250$ torr. $^{7}$ Consequently a significant fraction of the $\mathrm{Hg}$ could still be a vapor. This could explain why the $\mathrm{Hg}$ concentration is low in this off-gas deposit.

Table 1 Results from ICP-ES of the digestions for the Quencher samples.

Elements Measured by ICP-ES

Concentrations are given in weight percent

\begin{tabular}{|c|c|c|c|c|c|c|}
\hline Element & Quencher-1 & uencher- & uencher-3 & Average & $\%$ RSD & SB3 $^{\mathrm{b}}$ \\
\hline $\mathbf{A g}$ & 0.018 & 0.017 & 0.016 & 0.017 & 5 & 0.016 \\
\hline Al & 4.61 & 4.57 & 4.53 & 4.57 & 1 & 5.14 \\
\hline B & 0.30 & 0.32 & 0.31 & 0.31 & 4 & 0.015 \\
\hline $\mathbf{B a}$ & 0.040 & 0.040 & 0.042 & 0.041 & 2 & 0.048 \\
\hline $\mathbf{C a}$ & 1.12 & 1.53 & 1.49 & 1.38 & 16 & 1.61 \\
\hline Cd & 0.39 & 0.49 & 0.42 & 0.43 & 11 & 0.18 \\
\hline $\mathrm{Cr}$ & 0.077 & 0.074 & 0.068 & 0.073 & 6 & 0.11 \\
\hline $\mathrm{Cu}$ & 0.016 & 0.014 & 0.015 & 0.015 & 6 & 0.027 \\
\hline $\mathbf{F e}$ & 10.6 & 9.92 & 10.5 & 10.3 & 4 & 16.4 \\
\hline Hg & 0.15 & 0.15 & 0.12 & 0.14 & 12 & 0.15 \\
\hline $\mathbf{L i}$ & 0.17 & 0.18 & 0.18 & 0.18 & 2 & 0.039 \\
\hline Mg & 1.08 & 1.21 & 1.11 & 1.13 & 6 & 1.52 \\
\hline Mn & 2.45 & 2.35 & 2.40 & 2.40 & 2 & 3.56 \\
\hline $\mathbf{N a}$ & 4.73 & 4.88 & 4.57 & 4.73 & 3 & 13.1 \\
\hline $\mathbf{N i}$ & 0.63 & 0.59 & 0.62 & 0.61 & 3 & 0.98 \\
\hline $\mathbf{P}$ & 0.23 & 0.20 & 0.26 & 0.23 & 11 & 0.44 \\
\hline $\mathbf{S}$ & 1.65 & 1.88 & 1.98 & 1.84 & 9 & 0.38 \\
\hline $\mathbf{S i}$ & 4.40 & 3.54 & $\mathrm{a}$ & 3.97 & 15 & 1.06 \\
\hline $\mathrm{Sr}$ & 0.20 & 0.28 & 0.27 & 0.25 & 17 & 0.37 \\
\hline $\mathbf{T i}$ & 0.01 & 0.01 & 0.01 & 0.01 & 5 & 0.016 \\
\hline $\mathbf{U}$ & 5.68 & 5.47 & 5.06 & 5.40 & 6 & 6.77 \\
\hline
\end{tabular}

a) Indicates a peroxide fusion digestion method where only 2 replicates were analyzed.

b) SB-3 data can be found in Reference 5 . 
Table 2 Radionuclide results, measured by gamma counting, of the Quencher samples.

Radionuclides Measured by Gamma Counting

Concentrations are given in microcuries/grams

\begin{tabular}{ccc} 
Element & Quencher-1 & Quencher-2 \\
\hline Co-60 & $9.13 \mathrm{E}-01$ & $6.45 \mathrm{E}-01$ \\
Cs-137 & $2.30 \mathrm{E}+02$ & $2.72 \mathrm{E}+02$ \\
Eu-154 & $5.85 \mathrm{E}+00$ & $5.08 \mathrm{E}+00$ \\
Np-239 & ND & $7.07 \mathrm{E}-01$ \\
Am-241 & $1.86 \mathrm{E}+01$ & $1.34 \mathrm{E}+01$
\end{tabular}

\begin{tabular}{cc} 
Average & \%RSD \\
\hline $7.79 \mathrm{E}-01$ & 24 \\
$2.51 \mathrm{E}+02$ & 12 \\
$5.47 \mathrm{E}+00$ & 10 \\
NA & NA \\
$1.60 \mathrm{E}+01$ & 23
\end{tabular}

Table 3 Results from ICP-MS of the aqua regia digestion of the Quencher samples.

\begin{tabular}{|c|c|c|c|c|c|}
\hline \multicolumn{6}{|c|}{$\begin{array}{l}\text { Isotopes Measured by ICP-MS } \\
\text { Concentrations are given in weight percent }\end{array}$} \\
\hline Element & Quencher-1 & Quencher-2 & Quencher-3 & Average & \%RSD \\
\hline Tc-99 & $2.89 \mathrm{E}-03$ & $2.87 \mathrm{E}-03$ & $2.42 \mathrm{E}-03$ & $2.73 \mathrm{E}-03$ & 10 \\
\hline Ru-101 & $1.57 \mathrm{E}-02$ & $1.56 \mathrm{E}-02$ & $1.62 \mathrm{E}-02$ & $1.58 \mathrm{E}-02$ & 2 \\
\hline Ru-102 & $1.54 \mathrm{E}-02$ & $1.52 \mathrm{E}-02$ & $1.50 \mathrm{E}-02$ & $1.52 \mathrm{E}-02$ & 1 \\
\hline Rh-103 & $4.37 \mathrm{E}-03$ & $3.93 \mathrm{E}-03$ & 4.84E-03 & $4.38 \mathrm{E}-03$ & 10 \\
\hline Ru-104 & $1.02 \mathrm{E}-02$ & $9.54 \mathrm{E}-03$ & $1.14 \mathrm{E}-02$ & $1.04 \mathrm{E}-02$ & 9 \\
\hline Pd-105 & $6.45 \mathrm{E}-04$ & 7.84E-04 & $9.04 \mathrm{E}-04$ & $7.78 \mathrm{E}-04$ & 17 \\
\hline U-234 & $6.26 \mathrm{E}-04$ & 4.74E-04 & 4.91E-04 & $5.30 \mathrm{E}-04$ & 16 \\
\hline U-235 & 3.09E-02 & $2.81 \mathrm{E}-02$ & $2.74 \mathrm{E}-02$ & $2.88 \mathrm{E}-02$ & 6 \\
\hline U-236 & $1.03 \mathrm{E}-03$ & $1.48 \mathrm{E}-03$ & $1.42 \mathrm{E}-03$ & $1.31 \mathrm{E}-03$ & 19 \\
\hline Np-237 & $4.88 \mathrm{E}-03$ & $7.12 \mathrm{E}-03$ & $5.09 \mathrm{E}-03$ & $5.70 \mathrm{E}-03$ & 22 \\
\hline U-238 & $5.91 \mathrm{E}+00$ & $5.54 \mathrm{E}+00$ & $5.18 \mathrm{E}+00$ & $5.54 \mathrm{E}+00$ & 7 \\
\hline Pu-239 & $1.93 \mathrm{E}-02$ & $1.93 \mathrm{E}-02$ & $1.98 \mathrm{E}-02$ & $1.94 \mathrm{E}-02$ & 2 \\
\hline Pu-240 & 2.04E-03 & $1.85 \mathrm{E}-03$ & $1.61 \mathrm{E}-03$ & $1.83 \mathrm{E}-03$ & 12 \\
\hline
\end{tabular}

As shown in Table 4, the main elements contained in the sample from the SAS deposit were $22 \mathrm{wt} \% \mathrm{Si}$, $5.7 \mathrm{wt} \% \mathrm{Fe}, 4.7 \mathrm{wt} \% \mathrm{Hg}$ and $2.8 \mathrm{wt} \% \mathrm{Na}$. The high concentration of Si suggests that frit particles are depositing in the SAS. The $\mathrm{Si}$ is about five times higher in concentration in the SAS compared with the Quencher. Results also show the SAS sample to be high in mercury, especially compared to the Quencher. Replicate concentrations for $\mathrm{Hg}$ range from $3.42 \mathrm{wt} \%$ to $6.57 \mathrm{wt} \%$, as seen in Table 4. This variation could be due to mercury not being homogenously distributed throughout the sample. The SAS temperature (measured in the tank vapor space) is between $20^{\circ} \mathrm{C}$ and $25^{\circ} \mathrm{C}$. Consequently the vapor pressure of the $\mathrm{Hg}$ would be lowered to 0.001 to 0.002 torr. $^{7}$ This could explain why the $\mathrm{Hg}$ is much higher in the SAS sample than the Quencher sample. The elements that were higher in concentration in the SAS compared to the $\mathrm{SB} 3^{5}$ were $\mathrm{B}, \mathrm{Cd}, \mathrm{Li}, \mathrm{S}$ and $\mathrm{Si}$, as was seen with the Quencher, but also $\mathrm{Hg}$, as mentioned above. Both the Cs-137 (Table 5) and Tc-99 (Table 6) were higher in concentration in the SAS than in the Quencher sample. Tc-99 was approximately four times higher and Cs-137 was approximately doubled. 
Table 4 Results from ICP-ES of the digestions for the SAS samples.

Elements Measured by ICP-ES

Concentrations are given in weight percent

\begin{tabular}{|c|c|c|c|c|c|c|}
\hline Element & SAS-1 & SAS-2 & SAS-3 & Average & $\%$ RSD & SB3 ${ }^{b}$ \\
\hline$\overline{\mathrm{Ag}}$ & 0.031 & 0.025 & 0.038 & 0.031 & 21 & 0.016 \\
\hline Al & 0.36 & 0.27 & 0.34 & 0.33 & 15 & 5.14 \\
\hline B & 0.12 & 0.10 & 0.12 & 0.11 & 11 & 0.015 \\
\hline Ba & 0.014 & 0.016 & 0.015 & 0.015 & 8 & 0.048 \\
\hline $\mathrm{Ca}$ & 0.15 & 0.11 & 0.16 & 0.14 & 19 & 1.61 \\
\hline Cd & 1.05 & 0.93 & 1.00 & 0.99 & 6 & 0.175 \\
\hline $\mathrm{Cr}$ & 0.053 & 0.046 & 0.065 & 0.055 & 18 & 0.107 \\
\hline $\mathrm{Cu}$ & 0.009 & 0.007 & 0.009 & 0.009 & 12 & 0.027 \\
\hline $\mathrm{Fe}$ & 6.07 & 5.55 & 5.62 & 5.75 & 5 & 16.4 \\
\hline $\mathrm{Hg}$ & 3.42 & 6.57 & 4.31 & 4.77 & 34 & 0.146 \\
\hline $\mathbf{L i}$ & 0.11 & 0.11 & 0.11 & 0.11 & 4 & 0.039 \\
\hline Mg & 0.30 & 0.26 & 0.29 & 0.28 & 8 & 1.52 \\
\hline Mn & 0.96 & 0.81 & 0.90 & 0.89 & 9 & 3.56 \\
\hline $\mathbf{N a}$ & 2.90 & 2.53 & 3.02 & 2.82 & 9 & 13.1 \\
\hline $\mathbf{N i}$ & 0.36 & 0.34 & 0.36 & 0.35 & 3 & 0.983 \\
\hline $\mathbf{P}$ & ND & ND & ND & ND & ND & 0.440 \\
\hline $\mathbf{S}$ & 0.84 & 0.66 & 0.71 & 0.74 & 12 & 0.376 \\
\hline $\mathbf{S i}$ & 17.6 & 26.5 & $\mathrm{a}$ & 22.1 & 29 & 1.06 \\
\hline $\mathrm{Sr}$ & 0.06 & 0.06 & $\mathrm{a}$ & 0.06 & 4 & 0.366 \\
\hline Ti & 0.005 & 0.004 & 0.005 & 0.004 & 6 & 0.016 \\
\hline $\mathbf{U}$ & 0.29 & 0.21 & 0.31 & 0.27 & 20 & 6.77 \\
\hline
\end{tabular}

a) Indicates a peroxide fusion digestion method where only 2 replicates were analyzed.

b) SB-3 data can be found in Reference 5 .

Table 5 Radionuclide results, measured by gamma counting, of the SAS samples.

Radionuclides Measured by Gamma Counting Concentrations are given in microcuries/grams

\begin{tabular}{ccc} 
Element & SAS-1 & SAS-2 \\
\hline Co-60 & $3.83 \mathrm{E}-01$ & $3.36 \mathrm{E}-01$ \\
Cs-137 & $5.47 \mathrm{E}+02$ & $5.61 \mathrm{E}+02$ \\
Eu-154 & $7.03 \mathrm{E}-01$ & $7.07 \mathrm{E}-01$ \\
Np-239 & ND & $2.09 \mathrm{E}-01$ \\
Am-241 & $2.34 \mathrm{E}+00$ & $2.67 \mathrm{E}+00$
\end{tabular}

\begin{tabular}{cc} 
Average & \%RSD \\
\hline $3.59 \mathrm{E}-01$ & 9 \\
$5.54 \mathrm{E}+02$ & 2 \\
$7.05 \mathrm{E}-01$ & 0 \\
ND & ND \\
$2.50 \mathrm{E}+00$ & 9
\end{tabular}


Table 6 Results from ICP-MS of the aqua regia digestion of the SAS samples.

\begin{tabular}{|c|c|c|c|c|c|}
\hline \multicolumn{6}{|c|}{ Concentrations are given in weight percent } \\
\hline Element & SAS-1 & SAS-2 & SAS-3 & Average & $\%$ RSD \\
\hline Tc-99 & $8.86 \mathrm{E}-03$ & $7.84 \mathrm{E}-03$ & $8.34 \mathrm{E}-03$ & $8.35 \mathrm{E}-03$ & 6 \\
\hline Ru-101 & $9.50 \mathrm{E}-03$ & 9.34E-03 & $1.24 \mathrm{E}-02$ & $1.04 \mathrm{E}-02$ & 16 \\
\hline Ru-102 & $1.06 \mathrm{E}-02$ & $9.44 \mathrm{E}-03$ & $1.09 \mathrm{E}-02$ & $1.03 \mathrm{E}-02$ & 8 \\
\hline Rh-103 & $3.30 \mathrm{E}-03$ & 4.09E-03 & $2.72 \mathrm{E}-03$ & $3.37 \mathrm{E}-03$ & 20 \\
\hline Ru-104 & $6.61 \mathrm{E}-03$ & $6.96 \mathrm{E}-03$ & $6.87 \mathrm{E}-03$ & $6.81 \mathrm{E}-03$ & 3 \\
\hline Pd-105 & $1.08 \mathrm{E}-03$ & $1.22 \mathrm{E}-03$ & $1.06 \mathrm{E}-03$ & $1.12 \mathrm{E}-03$ & 8 \\
\hline U-234 & ND & ND & ND & ND & ND \\
\hline U-235 & $1.35 \mathrm{E}-03$ & $1.31 \mathrm{E}-03$ & $1.66 \mathrm{E}-03$ & $1.44 \mathrm{E}-03$ & 13 \\
\hline U-236 & ND & ND & ND & ND & ND \\
\hline Np-237 & ND & ND & ND & ND & ND \\
\hline U-238 & $3.04 \mathrm{E}-01$ & $2.21 \mathrm{E}-01$ & $3.29 \mathrm{E}-01$ & $2.85 \mathrm{E}-01$ & 20 \\
\hline Pu-239 & $9.29 \mathrm{E}-03$ & 7.83E-03 & $9.56 \mathrm{E}-03$ & 8.89E-03 & 10 \\
\hline Pu-240 & $1.02 \mathrm{E}-03$ & $7.57 \mathrm{E}-04$ & $1.21 \mathrm{E}-03$ & $9.95 \mathrm{E}-04$ & 23 \\
\hline
\end{tabular}

The results from the chemical composition suggest the samples are probably sludge and frit particles entrained in the off-gas.

In Table 7, the ratios of various elements can be found for the Quencher and SAS deposits along with respective ratios from $\mathrm{SB}^{5}$ results and the Frit 418 used to vitrify SB3. (The composition of Frit 418 is $76 \mathrm{wt} \% \mathrm{Si}, 8 \mathrm{wt} \% \mathrm{~B}, 8 \mathrm{wt} \% \mathrm{Li}$ and $8 \mathrm{wt} \% \mathrm{Na}^{8}{ }^{8}$ ) These ratios will be fed to the Process Science \& Engineering (PS\&E) melter and off-gas modeling program in an attempt to improve understanding of the off-gas system performance. One obvious conclusion can be drawn from the mercury to iron ratios. Note that the ratios for the off-gas deposits, including the Quencher deposits, are significantly higher than the ratio in SB3 sample. ${ }^{5}$ This indicates that there is more mercury in the off-gas than can be explained by entrainment only. After the SRAT, much of the mercury is in the elemental state and has a very high vapor pressure at the temperatures of the melter and vaporizes off into the off-gas. Also note that in the SAS sample, the mercury to iron ratio is higher than in the Quencher deposit indicating that the mercury is not holding up, again probably due to its volatility. 
Table 7 Ratio values of elements found in the Quencher and SAS compared to the same ratios from Sludge Batch 3 and Frit 418.

\begin{tabular}{ccccccccc} 
Ratio & Quencher 1 & Quencher 2 & Quencher 3 & SAS-1 & SAS-2 & SAS-3 & SB3 $^{\text {a }}$ & Frit 418 $^{\mathbf{b}}$ \\
\hline $\mathrm{Fe} / \mathrm{Al}$ & $2.30 \mathrm{E}+00$ & $2.17 \mathrm{E}+00$ & $2.32 \mathrm{E}+00$ & $1.66 \mathrm{E}+01$ & $2.03 \mathrm{E}+01$ & $1.63 \mathrm{E}+01$ & $3.19 \mathrm{E}+00$ & NA \\
$\mathrm{Fe} / \mathrm{Si}$ & $2.41 \mathrm{E}+00$ & $2.80 \mathrm{E}+00$ & $\mathrm{ND}$ & $3.45 \mathrm{E}-01$ & $2.09 \mathrm{E}-01$ & $\mathrm{ND}$ & $1.55 \mathrm{E}+01$ & $\mathrm{NA}$ \\
$\mathrm{Fe} / \mathrm{Sr}$ & $5.23 \mathrm{E}+01$ & $3.53 \mathrm{E}+01$ & $3.84 \mathrm{E}+01$ & $1.01 \mathrm{E}+02$ & $9.73 \mathrm{E}+01$ & $\mathrm{ND}$ & $4.48 \mathrm{E}+01$ & $\mathrm{NA}$ \\
$\mathrm{Fe} / \mathrm{U}$ & $1.87 \mathrm{E}+00$ & $1.81 \mathrm{E}+00$ & $2.07 \mathrm{E}+00$ & $2.08 \mathrm{E}+01$ & $2.68 \mathrm{E}+01$ & $1.83 \mathrm{E}+01$ & $2.42 \mathrm{E}+00$ & NA \\
$\mathrm{Hg} / \mathrm{Fe}$ & $1.41 \mathrm{E}-02$ & $1.48 \mathrm{E}-02$ & $1.14 \mathrm{E}-02$ & $5.63 \mathrm{E}-01$ & $1.18 \mathrm{E}+00$ & $7.67 \mathrm{E}-01$ & $8.90 \mathrm{E}-03$ & NA \\
$\mathrm{B} / \mathrm{Si}$ & $6.73 \mathrm{E}-02$ & $9.02 \mathrm{E}-02$ & $\mathrm{ND}$ & $6.77 \mathrm{E}-03$ & $3.79 \mathrm{E}-03$ & $\mathrm{ND}$ & $1.42 \mathrm{E}-02$ & $6.98 \mathrm{E}-02$ \\
$\mathrm{Li} / \mathrm{Si}$ & $3.94 \mathrm{E}-02$ & $5.09 \mathrm{E}-02$ & $\mathrm{ND}$ & $6.41 \mathrm{E}-03$ & $3.97 \mathrm{E}-03$ & $\mathrm{ND}$ & $3.63 \mathrm{E}-02$ & $1.05 \mathrm{E}-01$
\end{tabular}

a) SB-3 data can be found in Reference 5 .

b) Frit data can be found in Reference 8 .

Table 8 gives the results for the ratios of the concentrations of $\mathrm{Fe}$ to the sum of the fissile isotopes U-233, $\mathrm{Pu}-239$, and U-235 concentrations. Note that all are greater than 160 , the criticality safe ratio for DWPF sludge operations. ${ }^{9}$ In the off-gas deposits, the U-233 concentration was too low to be measured. Consequently, it was calculated from the U-233 and U-235 ratio measured in the SB3 sample since DWPF processing does not change the isotopic composition of the uranium during processing. ${ }^{10}$ As seen in Table 8, the ratio for the Quencher sample agrees reasonably well with the SB3 value, indicating no enhancement of fissile material in the sample. The ratios of iron to fissile are higher in the SAS samples indicating depletion of the fissile material in the samples further down the off-gas system. Results indicate that fissile material is not accumulating at these locations in the off-gas system relative to Fe.

Table 8 Ratio values of Fe compared to the sum of U-233, Pu-239 and U-235 for the Quencher and SAS samples and SB-3.

Ratio Quencher 1 Quencher 2 Quencher 3 SAS-1 SAS-2 $\quad$ SAS-3

a) U-233 was calculated by using the measured U-235 and U-233 concentration in SB3 (Reference 10).

b) SB-3 data can be found in Reference 5 .

\subsection{Water Leach of Samples}

Triplicate off-gas samples of each were leached with water at ambient temperature to determine the fraction of water soluble elements and anions that were in each of the samples. Studies made during vitrification of nonradioactive simulated sludges indicated that off-gas deposits contained water soluble 
alkali borates, halides, and sulfates. ${ }^{4}$ It was expected that if chlorides or fluorides were present in the radioactive off-gas samples, this technique would indicate their presence. The triplicate samples of the Quencher deposit and the SAS deposit were leached for $\sim 3.5$ days with intermittent shaking. After leaching, all the solutions still contained solids. Each leach solution was sampled and submitted to AD to be analyzed by ICP-ES for soluble elements. The solutions were also analyzed by Ion Chromatography (IC) to determine the amount of water soluble anions dissolved from the samples. Table 9 displays results of the leach tests calculated in terms of weight percent of the dissolved element or anion in the original sample. This was calculated by knowing the mass of dissolved element or anion (calculated from the volume of the final solution and the measured concentration of that element in the solution) and the mass of the sample that was leached. The fraction of the element dissolved could then be calculated by knowing the total amount of that element in the sample from the acid dissolutions. These fractions are shown in Table 10. Fractions of anions leached could not be calculated because the total amount of each anion in the original sample was not measured. For this calculation, the average of the respective concentrations of the elements in the samples were used (see Column 5 of Tables 1 and 4).

Table 9 Weight percent of elements and anions from the off-gas samples dissolved in water.

\begin{tabular}{|c|c|c|c|c|c|c|}
\hline & Quencher 1 & uencher & uencher 3 & SAS-1 & SAS-2 & SAS-3 \\
\hline Al & ND & ND & ND & 0.102 & 0.112 & 0.111 \\
\hline B & 0.193 & 0.198 & 0.182 & 0.076 & 0.076 & 0.075 \\
\hline $\mathrm{Ca}$ & 0.775 & 0.492 & 0.679 & 0.071 & 0.089 & 0.093 \\
\hline Cd & 0.009 & 0.005 & 0.007 & 0.434 & 0.498 & 0.479 \\
\hline $\mathrm{Cr}$ & 0.018 & 0.014 & 0.016 & ND & ND & ND \\
\hline $\mathrm{Hg}$ & $*$ & $*$ & $*$ & 0.352 & 0.382 & 0.427 \\
\hline $\mathbf{L i}$ & 0.028 & 0.030 & 0.026 & 0.056 & 0.060 & 0.059 \\
\hline Mg & 0.170 & 0.146 & 0.153 & 0.053 & 0.058 & 0.057 \\
\hline Mn & ND & ND & ND & 0.038 & 0.043 & 0.043 \\
\hline $\mathrm{Na}$ & 4.02 & 4.44 & 4.11 & 3.16 & 3.40 & 3.29 \\
\hline $\mathbf{N i}$ & ND & ND & ND & 0.006 & 0.007 & 0.007 \\
\hline $\mathbf{P}$ & ND & ND & ND & 0.010 & ND & 0.012 \\
\hline S & 2.24 & 1.87 & 2.11 & 0.768 & 0.823 & 0.800 \\
\hline Si & 0.030 & 0.039 & 0.025 & 0.109 & 0.114 & 0.118 \\
\hline $\mathrm{Sr}$ & 0.147 & 0.092 & 0.129 & 0.012 & 0.016 & 0.017 \\
\hline $\mathbf{U}$ & ND & ND & ND & 0.013 & 0.017 & 0.020 \\
\hline Fluoride & 0.17 & NA & 0.16 & 0.46 & 0.46 & 0.53 \\
\hline Chloride & 0.020 & NA & 0.017 & 0.18 & 0.20 & 0.20 \\
\hline Nitrite & 0.088 & NA & 0.087 & ND & ND & ND \\
\hline Nitrate & 5.74 & NA & 5.22 & 5.50 & 5.91 & 5.83 \\
\hline Sulfate & 4.55 & NA & 5.03 & 1.90 & 2.06 & 2.01 \\
\hline
\end{tabular}


Table 10 Fraction of elements or anions leached in the Quencher and SAS samples based on the wt\% of the sample from the digestions and the weight percent of the soluble elements from the water leach.

\begin{tabular}{|c|c|c|c|c|c|c|}
\hline & Quencher & uencher & uencher 3 & SAS-1 & SAS-2 & SAS-3 \\
\hline Al & ND & ND & ND & 0.310 & 0.341 & 0.340 \\
\hline B & 0.627 & 0.642 & 0.591 & 0.663 & 0.665 & 0.655 \\
\hline $\mathbf{C a}$ & 0.561 & 0.356 & 0.492 & 0.510 & 0.645 & 0.675 \\
\hline Cd & 0.020 & 0.013 & 0.017 & 0.436 & 0.500 & 0.481 \\
\hline $\mathrm{Cr}$ & 0.248 & 0.197 & 0.214 & ND & ND & ND \\
\hline Hg & * & * & * & 0.074 & 0.080 & 0.090 \\
\hline $\mathbf{L i}$ & 0.156 & 0.168 & 0.146 & 0.514 & 0.545 & 0.540 \\
\hline Mg & 0.150 & 0.128 & 0.135 & 0.187 & 0.206 & 0.203 \\
\hline Mn & ND & ND & ND & 0.043 & 0.049 & 0.048 \\
\hline $\mathbf{N a}$ & 0.850 & 0.939 & 0.869 & 1.12 & 1.21 & 1.17 \\
\hline $\mathbf{N i}$ & ND & ND & ND & 0.018 & 0.020 & 0.019 \\
\hline $\mathbf{P}$ & ND & ND & ND & ND & ND & ND \\
\hline $\mathbf{S}$ & 1.22 & 1.02 & 1.15 & 1.04 & 1.12 & 1.08 \\
\hline $\mathbf{S i}$ & 0.007 & 0.010 & 0.006 & 0.005 & 0.005 & 0.005 \\
\hline $\mathrm{Sr}$ & 0.584 & 0.366 & 0.511 & 0.210 & 0.276 & 0.287 \\
\hline $\mathbf{U}$ & ND & ND & ND & 0.049 & 0.064 & 0.073 \\
\hline
\end{tabular}

* indicates that the leachates from the Quencher sample were not measured for mercury. ND indicates that the element was not detected by the ICP-ES analysis.

Several observations can be made concerning the results in Table 9 and Table 10. These are listed below.

- Within the uncertainty of the results, it appears that all the $\mathrm{Na}$ and $\mathrm{S}$ in the Quencher and SAS deposits were soluble in water.

- For both the Quencher and SAS deposits, $59 \%$ to $67 \%$ of the B was soluble, probably as the borate anion.

- Comparing the IC results for sulfate with the ICP-ES results for S suggests that in both types of deposits, the $\mathrm{S}$ could have been primarily present as sulfate. This is in agreement with the earlier analyses of off-gas deposits. 3,4

- Nitrate was detected as the major soluble anion in the off-gas deposits with sulfate being next.

- In contrast to the results for the off-gas deposits analyzed in $2003,{ }^{3}$ soluble compounds of fluoride and chloride were detected; however, their concentrations in the Quencher and SAS deposits were less than one weight percent. It should be noted that soluble chloride and fluoride were very low ( 0.00074 and $0.0077 \mathrm{M}$, respectively) in the SB3 slurry supernate ${ }^{5}$ but they were still detected in the off-gas deposits. 
WSRC-STI-2007-00262

Revision 0

This page intentionally left blank. 


\subsection{CONCLUSIONS}

The following conclusion can be made about the Quencher and SAS samples from the analytical results in this report:

- The deposits are not high level waste glass from the DWPF melt pool based on comparison of the compositions of deposits to the composition of a sample of glass taken from the pour stream of the melter during processing of SB3.

- Chemical composition results suggest that the deposits are probably a combination of sludge and frit particles entrained in the off-gas. The Quencher sample contained $10 \mathrm{wt} \% \mathrm{Fe}, 5.4 \mathrm{wt} \%$ $\mathrm{U}, 4.7 \mathrm{wt} \% \mathrm{Na}, 4.5 \mathrm{wt} \% \mathrm{Al}, 4 \mathrm{wt} \% \mathrm{Si}, 2.4 \mathrm{wt} \% \mathrm{Mn}$, and $1.8 \mathrm{wt} \% \mathrm{~S}$ along with smaller amounts of elements from the high level waste sludge being processed. The SAS sample contained $22 \mathrm{wt} \% \mathrm{Si}, 5.7 \mathrm{wt} \% \mathrm{Fe}, 4.7 \mathrm{wt} \% \mathrm{Hg}, 2.8 \mathrm{wt} \% \mathrm{Na}$, and $0.9 \mathrm{wt} \% \mathrm{Mn}$.

- Gamma emitters, such as Co-60, Cs-137, Eu-154, Am-241, and Am-243 were detected in both the Quencher and SAS samples with Cs-137 having the highest concentration of the gamma emitters.

- No evidence existed for accumulation of fissile material (U-233, U-235, and Pu-239) relative to Fe in either deposit.

- XRD results indicated both samples were primarily amorphorous and contained some crystals of the iron oxides, hematite and magnetite $\left(\mathrm{Fe}_{2} \mathrm{O}_{3}\right.$ and $\left.\mathrm{Fe}\left(\mathrm{Fe}_{2} \mathrm{O}_{4}\right)\right)$, along with sodium nitrate $\left(\mathrm{NaNO}_{3}\right)$. The other main crystalline compound in the SAS deposit was mercurous chloride. The main crystalline compound in the Quencher deposit was a uranium oxide compound. These are all sludge components.

- SEM analysis of the Quencher deposit revealed crystalline uranium compounds within the sample. SEM analysis of the SAS sample could not be performed due to the presence of a significant concentration of $\mathrm{Hg}$ in the sample.

- Essentially all the $\mathrm{Na}$ and the $\mathrm{S}$ in the off-gas samples were soluble in water.

- The main soluble anion was $\mathrm{NO}_{3}{ }^{-}$with $\mathrm{SO}_{4}{ }^{2-}$ being second.

- In contrast to the results for the off-gas deposits analyzed in $2003,{ }^{3}$ soluble compounds of fluoride and chloride were detected; however, their concentrations in the Quencher and SAS deposits were less than one weight percent. It should be noted that soluble chloride and fluoride were very low (0.00074 and $0.0077 \mathrm{M}$, respectively) in the SB3 slurry supernate ${ }^{5}$ but they were still detected in the off-gas deposits.

- The results suggest that the $\mathrm{S}$ is primarily in the deposits as the sulfate anion. 
WSRC-STI-2007-00262

Revision 0

This page intentionally left blank. 


\subsection{REFERENCES}

1. Barnes, Allen, Characterize Melter Off-Gas Deposits, HLW-DWPF-TAR-2007-0005, January 30, 2007.

2. Defense Waste Processing Overview, Facility Systems Training Study Guide, W5BC200XSTGD000104, Rev. 4, Savannah River Site, Aiken, SC, January 2007.

3. Bibler, N., Characterization of Three Samples Taken From the Off-gas System of DWPF Melter One. WSRC-TR-2003-00423 Rev. 0, Savannah River Site, Aiken, SC, September 2003.

4. Jantzen, C. M., Glass Melter Off-Gas System Pluggages: Cause, Significance, and Remediation (U). WSRC-TR-90-205 Rev. 0, Savannah River Site, Aiken, SC, March 1991.

5. Bannochie, C. J., Fellinger, T. L. and Pareizs, J. M., Tank 40 Final SB3 Chemical Characterization Results. WSRC-TR-2005-00049 Rev. 0, Savannah River Site, Aiken, SC, January 2005.

6. Bannochie, C. J., and Bibler, N. E., Analysis of Sludge Batch 3 (MacroBatch 4) DWPF Pour Stream Glass Sample For Canister S02312. WSRC-TR-2005-00354 Rev. 0, Savannah River Site, Aiken, SC, August 2005.

7. Dean, J. H (Ed.), Lange's Handbook of Chemistry, 15th Edition, McGraw-Hill, Inc., NY, 1999.

8. Peeler, D. K., Edwards, T. B., Workman, R. J., and Reamer, I. A. The Impact of Waste Loading on Viscosity in the Frit 418-SB3 System. WSRC-TR-2004-00429 Rev. 0, Savannah River Site, Aiken, SC, August 2004.

9. Hack, J. D., Updated Nuclear Criticality Safety Analysis Summary Report The S-Area Defense Waste Processing Facility Sludge-Only Operations (U). WSRC-RP94-1132, Rev.1, Westinghouse Savannah River Co., Aiken, SC, December 1999.

10. Bannochie, C. J., and Bibler, N. E., Determination of Reportable Radionuclides for DWPF Sludge Batch 3 (Macrobatch 4). WSRC-TR-2005-00157 Rev. 0, Savannah River Site, Aiken, SC, May 2005. 
WSRC-STI-2007-00262

Revision 0

This page intentionally left blank. 


\subsection{ACKNOWLEDGEMENTS}

The authors wish to thank the following people for their assistance and helpful discussions: Leigh Brown, Art Jurgensen, Mike Summer, June Hart, Curtis Johnson, Jake Venzie, Chuck Coleman, Damon Click, Dave DiPrete, CeCi DiPrete, Amy Ekechukwu, Carol Jantzen, John Pareizs, Rita Sullivan, Mona Jenkins, and Debbie Burckhalter. 


\section{Distribution:}

J. E. Occhipinti, 704-S

A. B. Barnes, 704-30S

J. F. Iaukea, 704-30S

J. W. Ray, 704-S

R. T. McNew, 704-27S

P. M. Woodward, 704-27S

M. E. Stone, 999-W

J. M. Pareizs, 773-A

C. M. Jantzen, 773-A

R. E. Edwards, 773-A

D. C. Koopman, 999-W

B. R. Pickenheim, 999-W

A. S. Choi, 773-42A

D. P. Lambert, 773-A

D. K. Peeler, 999-W

M. E. Smith, 999-W

D. A. Crowley, 999-W

C. C. Herman, 773-42A

C. J. Bannochie, 773-42A

L.M. Chandler, 773-A

M. J. Barnes, 773-A

K. J. Imrich, 773-A

D. H. Miller, 999-W 